\title{
Abnormal DNA Repair
}

National Cancer Institute

\section{Source}

National Cancer Institute. Abnormal DNA Repair. NCI Thesaurus. Code C36335.

A defect in the repair of damaged DNA that results from variations or mutations in one or more genes encoding proteins involved in DNA repair pathways. 